\title{
Plant Growth Promoting Microorganism Selection and Activity Test for Reforestation of Topsoil Restoration Site
}

\author{
Ji Seul Kim ${ }^{\bullet}$ Jun Ho Kim ${ }^{\odot}$ Eun Young Lee ${ }^{\dagger \odot}$ \\ Department of Environmental, Energy Engineering, The University of Suwon, Republic of Korea
}

(Received November 29, 2021; Revised December 6, 2021; Accepted December 6, 2021)

Objectives: This study was conducted to investigate the applicability of plant growth promoting microorganisms during restoration through re-vegetation of damaged topsoil.

Methods: As the vegetation to be applied to the restoration site, Weigela subsessilis, Spiraea prunifolia, Pine densiflora, Pennisetum alopecuroides were selected. An attempt was made to isolate plant growth promoting microorganisms from the root zone of plants of the same species inhabiting domestic park sites and hiking trails. Plant growth promoting activities such as phosphate solubilization ability, siderophore production ability, IAA production ability, and ACC deaminase production ability were examined, and the species to be finally applied was selected and then identified. Among the strains whose plant growth promoting activity was confirmed, Arthrobacter sp. 1B2 and Paraburkholderia terrae 1P2 were applied to the genitalia and pine, respectively, and a pot experiment was conducted to confirm the activity.

Results and Discussion: Forty-five strains were isolated from Weigela subsessilis, Spiraea prunifolia, Pine densiflora, Pennisetum alopecuroides and the IAA-producing ability and ACC deaminase-producing ability were confirmed for 16 strains whose phosphate solubilizing ability and siderophore-producing ability were confirmed. After selecting and identifying strains with excellent plant growth promoting ability, strains such as Cupriavidus sp, Arthrobacter sp., Pseudomonas fluorescens, Pseudomonas sp., Paraburkholderia terrae were obtained. Among them, Arthrobacter sp. 1B2 and Paraburkholderia terrae 1P2 strains were applied to genitalia and pine, respectively, and it was confirmed that plant growth was promoted.

Conclusions: Bioassay experiments and field applications using plant growth promoting microorganisms have been mainly studied for herbaceous species (Grandaceae, corn, oats, etc.). However, in this study, the applied plants are shrubs class, which do not significantly grow in length, targeting damaged areas with high subsoil content, which are poor in environment and insufficient in organic and inorganic matter. Therefore, it is meaningful in that the activity of plant growth promoting microorganisms focused on absorption of inorganic substances, such as phosphate solubilization activity and siderophore ability, was investigated and the activity was confirmed by performing a bioassay.

Keywords: Topsoil, Restoration, Plant growth promoting rhizobacteria, Shrub plant 


\title{
연구논문
}

\section{표토복원지 재녹화를 위한 식물생장촉진 미생물 선별 및 활성 검사}

\author{
김지슬 ${ }^{\cdot}$ 김준호 ${ }^{\oplus} \cdot$ 이은영 ${ }^{\dagger}$
}

수원대학교 환경에너지공학과

목적 : 본 연구는 훼손된 표토의 재식생화를 통한 복원 중 식물생장촉진미생물의 적용 가능성을 알아보기 위하여 수행되었다.

방법: 현장 복원지에 적용할 식생으로 병꽃나무, 조팝나무, 소나무 및 슈크령을 선정하였다. 국내 공원부지 및 등 산 산책로 등에 서식하는 동일한 종의 식물 근권으로부터 식물생장촉진미생물의 분리를 시도하였다. 인산가용화 능, siderophore 생성능, IAA생성능, ACC deaminase 활성능 등의 식물생장촉진 활성을 검사하여 최종 적용할 종을 선정한 후 동정하였다. 식물생장촉진활성이 확인된 균주 중 Arthrobacter sp. 와 Paraburkholderia terrae를 각각 병 꽃나무와 소나무에 적용하여 활성을 확인하기 위한 pot 실험을 진행하였다.

결과 및 토의: 병꽃나무, 조팝나무, 소나무, 및 슈크령으로부터 45 개의 균주를 분리하였고, 인산가용화능과 siderophore 생성능이 확인된 16개의 균주를 대상으로 IAA생성능, ACC deaminase 활성능을 확인하였다. 식물생장 촉진능이 우수한 균주를 선정 후 동정하여 Cupriavidus sp, Arthrobacter sp., Pseudomonas fluorescens, Pseudomonas sp., Paraburkholderia terrae 등의 균주를 확보하였다. 이 중 Arthrobacter sp. 1B2와 Paraburkholderia terrae 1P2 균 주를 각각 병꽃나무와 소나무에 적용하여 식물생장이 촉진됨을 확인하였다.

결론 : 식물생장촉진미생물을 이용한 생물검정 실험 및 현장적용은 주로 초본류(벼과, 옥수수, 귀리 등)를 대상으로 연구되어왔다. 그러나 본 연구에서는 환경이 열악하고 유기물과 무기물의 함량이 부족한 심토 함량이 높은 훼손지 를 대상으로 적용 대상 식물이 관목류로서 길이 생장이 현저하게 진행되지 않는 식물이다. 따라서, 인산가용화 활 성 및 siderophore능과 같이 무기물의 흡수에 초점을 둔 식물생장촉진미생물의 활성에 알아보고 생물검정을 수행 하여 활성을 확인한 점에서 의의가 있다.

주제어: 표토, 복원, 식물생장촉진미생물, 관목

\section{1. 서론}

표토는 주로 경작지에서 경운되는 약 $30 \mathrm{~cm}$ 깊이의 토양층 이며, 식물의 뿌리가 닿는 부분으로 산소를 머금고 천천히 방 출함으로써 근권부의 혐기화를 억제할 수 있어야 하며, 영양 분을 함유하여 심토와 함께 수분을 유지하며 건기 동안 식물 의 생장을 유지할 수 있도록 해야 한다. 심토는 대부분의 토양 에서 필수적인 구성요소로써 수분을 저장하여 더 깊은 층이나 수로로 강우를 전달케 하며, 나무, 관목 및 풀이 깊은 뿌리를 내릴 수 있도록 하여 여름의 가뭄을 이겨내고 고정해주는 역 할을 해주며, 지표수의 유출과 침수를 제어해줄 수 있다. ${ }^{1)}$

표토 $1 \mathrm{~cm}$ 가 만들어지기 위해서는 $100 \sim 300$ 년의 시간이 필 요하다. 표토는 단순한 ‘흙’이 아닌 ‘질 높은 자원’이며, 유기물, 미생물이 풍부해 식물의 생장에 필요한 양분을 저장하고 공급 할 뿐 아니라, 자연정화, 탄소저장, 대기 냉각 등의 물질순환의
기능과 환경적 순기능으로 약 26.4 조원의 환경적 가치를 가지 고 있다. ${ }^{2)}$ 그러나 경제협력개발기구(OECD)의 토양유실량 분 류기준과 비교 시 전국 평균 표토유실량 평균치가 매우 심함을 알 수 있다. ${ }^{1}$ 산악지형이 많고, 여름철 집중 강수가 내리는 우 리나라의 지형적·기후적 특성으로 인하여 표토 침식에 매우 취약하여 국토의 $30 \%$ 이상에서 연간 33 톤/ha을 초과하는 표 토가 유실되는 것으로 파악돼 체계적인 관리가 필요한 상태 다. ${ }^{1)}$ 자연적인 훼손은 대부분 강우나 바람 등의 자연적인 원인 으로 발생하고 인위적인 훼손은 도시화에 의한 개발이나 벌목 등으로 발생하며 해마다 표토가 약 $50 \mathrm{~km}^{2}$ 씩 감소하는 실정 이며, 대지, 도로, 및 철도건설 등으로 연간 447 만 $\mathrm{m}^{3}$ 의 표토 유실이 예상된다. 건설공사의 토지 절·성토 과정에서 지반 표 토를 수거한 후 별도로 보전하지 않고 건축 부지 정지 후 건축 물을 조성한다. ${ }^{1)}$ 이 후 부지내로 식재기반을 조성하는 단계에 서는 이미 양호한 표토를 소실하였기 때문에 별도의 객토를 
행하는 등 자원보존도 이루어지지 않고 식재 후 안착하지 못 하는 상황이 반복된다. 강원지역 대관령 고랭지에서는 수년간 의 토사 침식으로 토양층의 대부분이 유실되어 생산성이 떨어 지고 폐경화된 부지가 늘어나고 있다. ${ }^{3)}$ 토양침식에 대한 중요 성은 최근까지 인식하지 못했었으나, 환경보존에 대한 인식이 높아짐에 따라 토양보존 및 훼손토 복원에 대한 관심이 높아 지고 있다. 또한 표토 복원을 위하여 저렴하고 손쉽게 구할 수 있는 정화토를 비롯한 유사토양을 성토재로 활용하고 있기 도 하여 포토의 기능에 대한 심도 있는 연구가 필요하다.

국내 이동토 및 유실토의 복원기술은 아직 기초적인 단계이 며, 국외의 복원기술은 영국을 비롯한 유럽 등에서 다양하게 수행 중이다. 주로, 심토 상부 유기물과 혼합토를 살포하는 in-situ기술과 유기물, 광물질을 혼합하거나 표토를 혼합하는 ex-situ 방법으로 구분된다. 표토복원 후 표토의 사후관리도 매우 중요한데, 이는 이후 토양 손상을 최소화할 수 있으며, 식물의 식재를 통해 관리될 수 있다.

훼손토 복원기술의 하나인 식재를 이용한 관리에서 식물의 생육은 가장 중요한 성공 요인이다. 식물은 생육에 필요한 여러 가지 호르몬을 체내에서 합성하지만, 외부에서 공급되 는 호르몬의 영향을 받기도 하며,4) 특히 식물호르몬을 생산 하는 미생물의 영향을 많이 받는다. 식물 뿌리의 생리작용에 영향을 받는 토양 권역인 근권은 뿌리표면으로부터 수 $\mathrm{mm}$ $\sim 1 \mathrm{~cm}$ 범위에 해당된다. 이 근권은 식물의 뿌리가 성장하는 동안 다양한 물질을 배출하고 흡수하여 토양의 환경을 형성 하고 토양 미생물의 활성에 유리한 환경을 제공한다. 이러 한 토양권역에서 서식하는 미생물을 근권미생물(rhizosphere microorganism)이라고 하며, 이 미생물 중에서 식물의 뿌리의 표면 또는 내부에 정착하여 식물의 생장을 촉진하는 토양 세균 을 식물생장촉진근권세균(plant growth-promoting rhizobacteria, PGPR)이라 한다. ${ }^{5}$ 식물 뿌리는 토양 근권에 서식하는 미생물 의 생장에 도움이 되는 저분자 탄소원을 방출하고, 근권에 서 식하는 유용 미생물은 다양한 기능을 통해 식물의 생장에 도 움을 줌으로서 서로 공생관계를 유지한다. 근권미생물은 대기 중의 질소를 고정시키거나, ${ }^{6}$ 인을 흡수하거나, ${ }^{7)} \mathrm{K}$ 을 가용화 ${ }^{8}$ 시킴으로서 주요 영양분 $(\mathrm{N}, \mathrm{P}, \mathrm{K})$ 의 흡수를 향상시키고, $\mathrm{Fe}$, $\mathrm{Mn}, \mathrm{Zn}, \mathrm{Si}$ 와 같은 미량원소를 가용화,10)시켜 줌으로 식물로 의 흡수를 향상시켜준다. 질소고정세균은 대기 중의 질소를 식물이 이용할 수 있는 질소화합물의 형태로 고정화하여 식물 생장에 필수적인 주요영양소를 제공하며 식물과 공생하는 Rhizobium sp.와 Bradyrhizobium sp.와 Azosporillum sp. 및 Pseudomonas sp. 등의 비공생형의 세균이 있다. ${ }^{11)}$ 불용성의 인을 가용화함으로서 영양분을 제공할 수 있는 세균으로는 Pseudomonas와 Burkholdera 등이 알려져 있다. ${ }^{12,13)}$ 또 다른 기능 으로는 생장호르몬인 indole-3-acetic acid (IAA) 및 siderophore 를 생성하거나, 질병 방지를 위한 항생물질을 생성함으로 식 물병원성 곰팡이의 생장을 억제하여 식물생장에 도움을 준
다. ${ }^{14)}$ 또한 PGPR은 식물의 성장을 유도하는 2 차 화합물과 휘 발성 유기 화합물(VOCs)을 생성한다. ${ }^{15)}$ 철은 모든 생명체에 필 수적으로 요구되는 미량원소이나, 일반적으로 호기적 환경에서 는 불용성 철화합물로 존재하고 있는데 이 경우 bioavailability 가 낮다. 미생물 중에는 철과 매우 친화력이 높은 저분자 킬러 이터인 siderophore를 분비하여 환경으로부터 철을 손쉽게 흡 수할 수 있도록 해준다. Chryseobacterium 등이 식물에 철을 제공하여 식물 생장을 촉진하는 것으로 알려져 있다. ${ }^{16}$

식물은 스트레스 환경(오염물질, 염분, 수분부족)에 노출되면 스트 레스 호르몬인 에틸렌과 그 전구체인 ACC (1-aminocyclopropane -1-carboxylic acid)의 축적을 통해 뿌리의 성장을 저해하고 식물 의 노화나 과성숙을 유도하여 시들어 죽게 한다. ${ }^{17)}$ 이때 $\mathrm{ACC}$ 가 풍부해진 근권토양은 $\mathrm{ACC}$ 를 질소원으로 이용하는 근권미생 물의 군집화를 유도하고, ${ }^{18)}$ 이들은 ACC deaminase 효소를 이용하여 에틸렌의 전구체인 $\mathrm{ACC}$ 를 ammonia와 a-ketobutyrate 로 분해하여 식물체 내의 에틸렌의 수준을 낮춰 식물의 생장에 도움을 준다. ${ }^{19)} \mathrm{ACC}$ deaminase를 생산하는 세균은 식물 뿌리 생장 을 촉진하고 식물에 대한 영양분 흡수도 촉진하는 것으로 알려져 있으며, ${ }^{20)}$ 대표적인 세균으로는 Microbispora, Streptomyces, Variovorax, Mesorhizobium 등이 알려져 있다. ${ }^{21)}$ 이와 같이 식물생장을 촉진하는 미생물은 다양한 효소활성을 통해 식물 에 이익을 주며, 식물이 배출하는 뿌리삼출물을 받아 생장하 기에 둘은 상호공생관계로 유지한다. ${ }^{22)}$ 현재까지 보고된 PGPR은 Pseudomonas, Azospirillum, Azotobacter, Klebsiella, Enterobacter, Alcaligens, Arthobacter, Burkholderia, Bacillus 를 포함하여 다양한 미생물이 있는 것으로 알려져 있다. ${ }^{23,24)}$

표토와 심토를 혼합 후 표토화 복원을 촉진하기 위하여 재 식재를 할 경우 혼합토양은 식생의 생장에 부적합하다. 이 경 우 식물의 초기 정착을 도와주기 위한 PGPR의 활성이 중요한 성공 요인이 될 수 있다. 특히, 무기물이 부족할 경우에 무기 물의 흡수를 도와주거나, 스트레스 환경에서 ACC deaminase 와 같은 효소활성을 가진 PGPR은 식물의 초기 정착을 도와주 는 유용한 역할을 할 것이다.

본 연구에서는 먼저 훼손토 복원지에 적용할 식물로 병꽃나 무, 조팝나무, 소나무 등의 관목과 초본류로 슈크령을 선정하 였다. 이후 각 식물에 적합한 근권미생물의 분리원으로 전국 산야에 자라는 낙엽관목의 병꽃나무, 조팝나무와 상록 침엽수 인 소나무와 여러해살이풀인 수크령을 대상으로 식물의 생장 을 향상시키는 PGPR을 분리하고자 하였다. 각 식물 근권의 미생물을 탐색 후 분리하고 활성 검사를 통하여 현장 적용 가능성을 알아보았다.

\section{2. 실험방법(또는 재료 및 방법)}

\section{1. 식물생장촉진 근권미생물의 분리 및 동정}

본 연구에서 사용한 토양은 경북 $\mathrm{A}$ 시에 위치한 생태공원에 
식재된 병꽃나무(Weigela subsessilis) 주위, 경기도 Y시 생태 공원에 식재된 조팝나무(Spiraea prunifolia)주위, 경기도 $\mathrm{H}$ 시 $\mathrm{S}$ 대학교내 도로변에 식재된 소나무(Pine densiflora) 주위, 경 기도 Y시 등산로의 슈크령(Pennisetum alopecuroides)이 분포 된 근권토양을 대상으로 하였다. 토양을 채취한 후 멸균수 $100 \mathrm{~mL}$ 가 들어있는 $250 \mathrm{~mL}$ 삼각플라스크에 $10 \mathrm{~g}$ 을 넣고 30 ${ }^{\circ} \mathrm{C}, 150 \mathrm{rpm}$ 으로 30 분 동안 진탕배양을 하였다. 연속희석법을 이용하여 Nutrient agar (NA) 배지에 $10^{4}$ 부터 $10^{7}$ 까지 도말하 여 $30^{\circ} \mathrm{C}$ 에서 7 일간 배양하였다. 배양된 배지에서 콜로니를 선 별하여 각각 초기 배지에 도말하고 순수 분리하였다. 이후 아 래의 다양한 식물생장활성 테스트 후 최종 선별된 균주에 대 한 동정을 실시하였다.

분리된 균주의 동정을 위하여 $16 \mathrm{~S} \mathrm{rRNA}$ 유전자를 분석하였 으며, 유전자 단편의 염기서열 분석은 Bio D co. Ltd. (Korea)에 의뢰한 후 동정된 결과를 이용하였다.

\section{2. 인산가용화능}

채취된 토양으로부터 구축된 colony library를 대상으로 다양 한 식물생장촉진 활성을 알아보았다. 그 중 식물 생장에 필요 한 영양분 중 제한요소로 작용하는 인산을 식물에게 제공하 는데 도움이 되는 인산 가용화활성은 다음과 같은 방법으로 수행하였다: 인산가용화 활성테스트 용 배지는 Pikovskaya's modified agar와 NBRIP-BPB agar (National Botanical Research Institute's phosphate growth medium with $0.025 \mathrm{~g} / \mathrm{L}$ bromophenol blue)를 이용하였다. 두 배지에 분리된 colony를 접종 후 $30^{\circ} \mathrm{C}$, 7일간 배양한 후 투명대(clear zone)가 생기면 양성반응으로 간주하였다. Pikovskaya's modified agar 배지의 조성은 다음과 같다. Glucose, $10 \mathrm{~g} ; \mathrm{NaCl}, 0.3 \mathrm{~g} ; \mathrm{Ca}_{3}\left(\mathrm{PO}_{4}\right)_{2}, 10 \mathrm{~g} ; \mathrm{MgSO}_{4}$. $7 \mathrm{H}_{2} \mathrm{O}, 0.3 \mathrm{~g} ; \mathrm{KCl}, 0.3 \mathrm{~g}$; $\left(\mathrm{NH}_{4}\right)_{2} \mathrm{SO}_{4}, 0.5 \mathrm{~g} ; \mathrm{FeSO}_{4} \cdot 7 \mathrm{H}_{2} \mathrm{O}, 0.03$ $\mathrm{g} ; \mathrm{MnSO}_{4} \cdot 4 \mathrm{H}_{2} \mathrm{O}, 0.03 \mathrm{~g}$; 증류수, $1 \mathrm{~L} . \mathrm{NBRIP-BPB}$ agar 배지 의 조성은 다음과 같다. Glucose, $10 \mathrm{~g} ; \mathrm{MgCl}_{2} \cdot 6 \mathrm{H}_{2} \mathrm{O}, 5 \mathrm{~g}$; $\mathrm{Ca}_{3}\left(\mathrm{PO}_{4}\right)_{2}, 5 \mathrm{~g} ; \mathrm{MgSO}_{4} \cdot 7 \mathrm{H}_{2} \mathrm{O}, 0.25 \mathrm{~g} ; \mathrm{KCl}, 0.2 \mathrm{~g} ;\left(\mathrm{NH}_{4}\right)_{2} \mathrm{SO}_{4}$, $0.1 \mathrm{~g}$; $\mathrm{BPB}$ (bromophenol blue), $0.025 \mathrm{~g}$; 증류수, $1 \mathrm{~L}$.

\subsection{Siderophore 생성능}

Siderophore 합성능은 고체배지를 이용하여 알아보는 기존 전통적인 방법인 Chrom azurol S (CAS) blue agar plate assay 방법을 이용하였다.25) (1) siderophores indicator인 blue dye solution은 $60.5 \mathrm{mg}$ 의 CAS를 $50 \mathrm{~mL}$ 증류수에 녹인 다음 1 $\mathrm{mM} \mathrm{FeCl} 3^{3} \cdot 6 \mathrm{H}_{2} \mathrm{O}$ 과 $10 \mathrm{mM} \mathrm{HCl}$ 이 첨가된 iron (III) solution을 $10 \mathrm{~mL}$ 첨가한 후, $40 \mathrm{~mL}$ 증류수에 $72.9 \mathrm{mg} \mathrm{HDTMA}$ 을 녹인 solution을 함께 하여 멸균한다. 또한, (2) medium solution $\left(750 \mathrm{~mL}\right.$ 증류수에 $100 \mathrm{~mL} 10 \mathrm{X} \mathrm{MM} 9$ salts $\left(\mathrm{Na}_{2} \mathrm{HPO}_{4}, 60 \mathrm{~g} / \mathrm{L}\right.$; $\left.\mathrm{KH}_{2} \mathrm{PO}_{4} 0.9 \mathrm{~g} / \mathrm{L} ; \mathrm{NaCl} 5 \mathrm{~g} / \mathrm{L} ; \mathrm{NH}_{4} \mathrm{Cl} 10 \mathrm{~g} / \mathrm{L}\right), 15 \mathrm{~g}$ 의 agar, $30.24 \mathrm{~g}$ 의 PIPES 그리고 $12.0 \mathrm{~g}$ 의 $50 \%(\mathrm{w} / \mathrm{w}) \mathrm{NaOH}$ 를 넣고 멸균하여 $50^{\circ} \mathrm{C}$ 로 식힌 후, $30 \mathrm{~mL}$ casamino acids $(10 \%, \mathrm{w} / \mathrm{v})$,
$10 \mathrm{~mL}$ glucose $(20 \%, \mathrm{w} / \mathrm{v}), 1 \mathrm{~mL}$ thiamine $\cdot \mathrm{HCl}(0.2 \%, \mathrm{w} / \mathrm{v})$, 그리고 $3 \mathrm{~mL} \mathrm{~L}$-tryptophane $(1 \%, \mathrm{w} / \mathrm{v})$ 를 첨가한다)을 제조한 후, (1)과 (2)를 잘 섞은 후, petri dish에 $30 \mathrm{~mL}$ 씩 군혀 $\mathrm{CAS}$ blue agar plate를 만들었다. 각각의 세균을 CAS blue agar plate에 접종하여 $30^{\circ} \mathrm{C}$ 에서 7일 동안 배양하였으며, colony 주 변에 orange halo가 형성되는 경우를 siderophores 합성 양성 으로 평가하였다.

\subsection{Indole-3-acetic acid (IAA) 생성능}

분리된 colony들을 대상으로 IAA 생산능을 평가하였다. 5 $\mathrm{mM}$ tryptophan을 첨가한 $\mathrm{DF}$ 배지(또는 $\mathrm{LB}$ broth) $3 \mathrm{~mL}$ 에 균주 배양액을 $1 \%(\mathrm{v} / \mathrm{v})$ 가 되도록 접종하여 $30^{\circ} \mathrm{C}$ 에서 180 $\mathrm{rpm}$ 으로 6일간 배양하였다. DF배지의 조성은 Hong과 Lee (2014) 및 Hong 등(2016)의 연구에 따라 만들어서 이용하였 다. ${ }^{17,26)} 14,000 \mathrm{rpm}$ 에서 10 분을 원심분리한 배양액을 $0.2 \mu \mathrm{m}$ pore-size filter을 이용하여 거른 상등액과 Salkowski reagent $\left(35 \% \mathrm{HClO}_{4}, 49 \mathrm{~mL} ; 0.5 \mathrm{M} \mathrm{FeCl}_{3}\right.$ solution $1 \mathrm{~mL}$ )을 1:2(v:v) 비율로 섞은 후, 어두운 곳에서 25-30분간 정치하였다. 분홍색 으로 발색되는 정도를 흡광광도계 DR 5000 (Hach, USA)을 이용하여 $530 \mathrm{~nm}$ 에서 측정하였다. 표준물질로 Indole-3-acetic acid $\left(\mathrm{C}_{8} \mathrm{H}_{5} \mathrm{~N}-\mathrm{CH}_{2} \mathrm{COOH}\right.$, SHOWA chemical Co., Japan)를 사 용하여 위와 동일한 방법으로 실험한 후 검량선을 작성하여 실험에 이용한 시료의 농도로 환산하였다.

$\mathrm{DF}$ 배지 조성은 다음과 같다. $\left(\mathrm{NH}_{4}\right)_{2} \mathrm{SO}_{4}, 2 \mathrm{~g} ; \mathrm{KH}_{2} \mathrm{PO}_{4}, 4$ g; $\mathrm{Na}_{2} \mathrm{HPO}_{4} \cdot 12 \mathrm{H}_{2} \mathrm{O}, 15 \mathrm{~g} ; \mathrm{MgSO}_{4} \cdot 7 \mathrm{H}_{2} \mathrm{O}, 0.2 \mathrm{~g} ; \mathrm{FeSO}_{4} \cdot 7 \mathrm{H}_{2} \mathrm{O}$, $1.0 \mathrm{mg}$; B (as $\left.\mathrm{H}_{3} \mathrm{BO}_{3}\right), 10 \mu \mathrm{g}$; $\mathrm{Mn}\left(\right.$ as $\left.\mathrm{MnSO}_{4} \cdot \mathrm{H}_{2} \mathrm{O}\right), 11 \mu \mathrm{g}$; $\mathrm{Zn}\left(\right.$ as $\left.\mathrm{ZnSO}_{4} \cdot 7 \mathrm{H}_{2} \mathrm{O}\right), 125 \mu \mathrm{g}$; $\mathrm{Cu}\left(\right.$ as $\left.\mathrm{CuSO}_{4} \cdot 5 \mathrm{H}_{2} \mathrm{O}\right), 78 \mu \mathrm{g}$; $\mathrm{Mo}\left(\mathrm{asNa}_{2} \mathrm{MoO}_{4} \cdot 2 \mathrm{H}_{2} \mathrm{O}\right), 17 \mu \mathrm{g}$; 증류수, $1 \mathrm{~L}$.

\subsection{ACC deaminase 활성 테스트}

ACC deaminase 활성은 Dell'Ammico 등(2005)과 같은 방법 으로 평가하였다. ${ }^{27)}$ 사용된 배지에 $\left(\mathrm{NH}_{4}\right)_{2} \mathrm{SO}_{4}$ 대신 $3 \mathrm{mM}$ $\mathrm{ACC}$ 를 넣은 $\mathrm{DF}$ 배지를 이용하였다. 분리된 각각의 colony를 배지에 접종하여 $30^{\circ} \mathrm{C}$ 에서 $180 \mathrm{rpm}$ 으로 6 일간 배양하였고, 배양기간 흡광광도계 DR 5000 (Hach, USA)을 이용하여 24시 간마다 $595 \mathrm{~nm}$ 에서 측정하여 분리된 균주의 생장정도로 $\mathrm{ACC}$ deaminase의 생성을 확인하였다. 유일 질소원인 $\mathrm{ACC}$ 를 이용하여 생장한 미생물의 생장 정도를 측정한 흡광도 값의 차이를 ACC deaminase의 효소 활성 결과로 해석할 수 있다.

\section{6. 소규모 POT 실험}

연구에 사용된 토양은 교내 뒷산에 있는 산 토양을 사용하 였고, 식물은 서울시 $\mathrm{G}$ 구의 꽃시장에서 구매한 소나무 묘목 9그루와 자색병꽃나무 묘목 6그루를 구매하여 사용하였다. 소 나무 묘목은 토양에 미생물을 주입하지 않은 3 그루의 대조군 과 미생물을 주입한 6 그루의 실험군으로 나누었고, 자색병꽃 
나무 묘목은 미생물을 주입하지 않은 3그루의 대조군과 미생 물을 주입한 3그루의 실험군으로 나누었다. 실험군과 대조군 을 비교하여 식물의 높이와 엽록소, 탈수소효소를 측정하였 다. 실험 시작 시 병꽃나무의 잎을 모두 제거하고 줄기를 동일 한 길이로 절단하였으며, 소나무의 경우는 줄기만 동일한 길 이로 절단하였다.

\section{3. 결과 및 고찰}

\section{1. 미생물 분리}

훼손 복원지로 적용할 식물의 생장을 향상시킬 수 있는 근 권미생물은 인근 지역 대상 식물이 서식하고 있는 근권토양을 채취하여 분리하였다. 토양 현탁액을 도말한 후 배지에 출현 한 콜로니 중에서 모양 및 색등의 형태적 차이가 있는 것들을 선별한 후에 새로운 배지로 계대배양하였다.

병꽃나무, 조팝나무, 소나무 및 수크령이 서식하고 있는 각 근권토양에서 각각 12 개, 22 개, 5 개, 6 개의 균주를 분리하였 다. 분리된 45 개의 균주를 가지고 식물 생장촉진 활성을 검사 하였다. 일차적으로 인산가용화능과 siderophore 활성능을 검 사한 후 그 중 양성 활성능을 가진 균주를 대상으로 IAA 및 ACC deaminase 활성을 검사하였다.

최종 선별된 균주는 인산가용화능, siderophore 활성능 및 IAA 생성과, ACC deaminase 활성을 보였으며 병꽃나무, 조 팝나무 및 소나무 근권에서 분리되어 각각 Arthrobacter sp. 1B2, Pseudomonas sp. 1JN2 및 Paraburkholderia terrae 1P2 로 동정되었다.

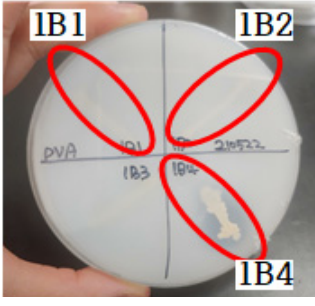

(a)

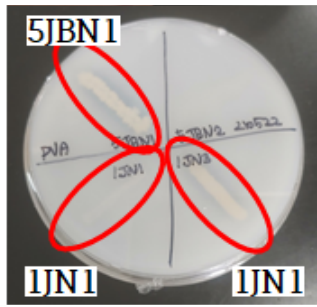

(e)

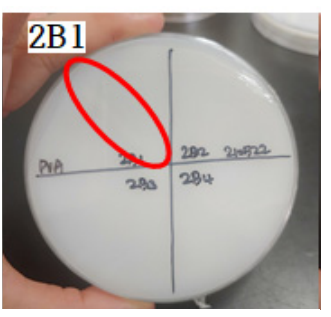

(b)

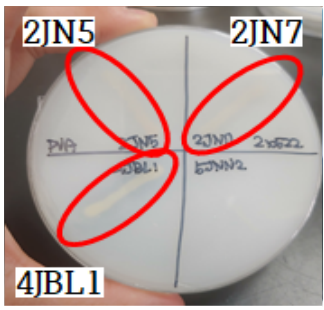

(f)

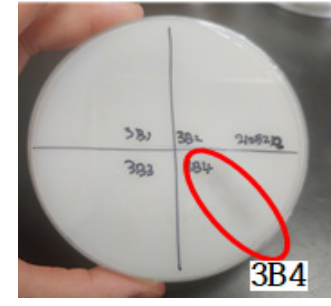

(c)

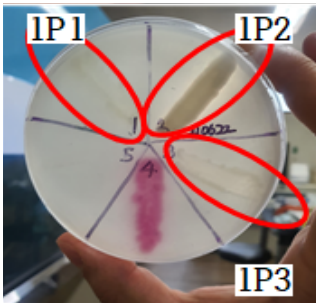

(g)

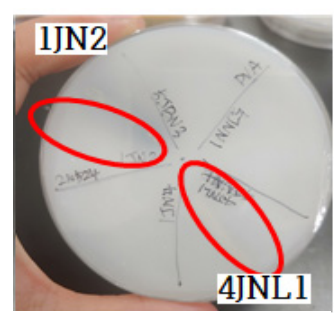

(d)

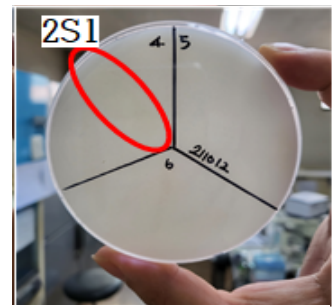

(h)

Fig. 1. Phosphoric acid solubility test using PVA medium. (a), Isolated strains 1B1, 1B2, 1B3, and 1B4 from Weigela subsessilis, (b), Isolated strains 2B1, 2B2, 2B3, and 2B4 from Weigela subsessilis; (c), Isolated strains 3B1, 3B2, 3B3, and 3B4 from Weigela subsessilis; (d), Isolated strains 1JN2, 1JN4, 4JNL1, 5JNN1 and 5JBN3 from Spiraea prunifolia;(e), Isolated strains 5JBN1, 1JN1, 1JN3 and 5JBN2 from Spiraea prunifolia;(f), Isolated strains 2JN5, 4JBL1, 5JNN2 and 2JN7 from Spiraea prunifolia; (g), Isolated strains 1P1, 1P2, 1P3, 1P4 and 1P5 from Pine densiflora; (h), Isolated strains 2S1, 2S2 and 2S3 from Pennisetum alopecuroides. 


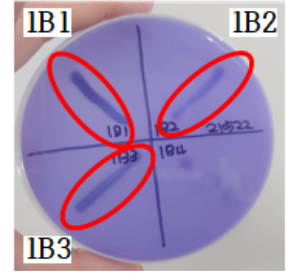

(a)

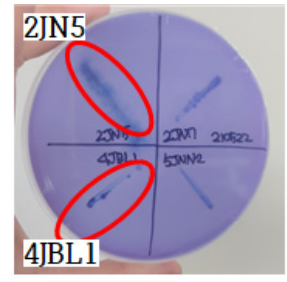

(f)

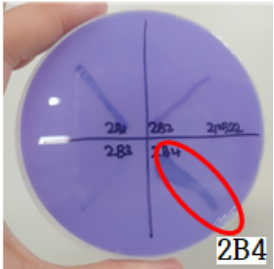

(b)

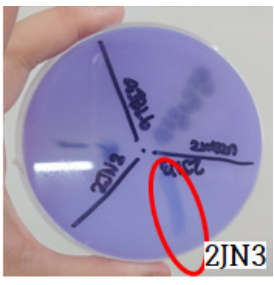

(g)

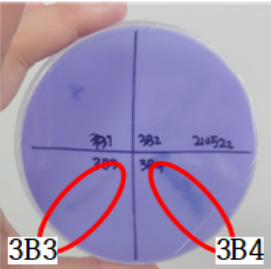

(c)

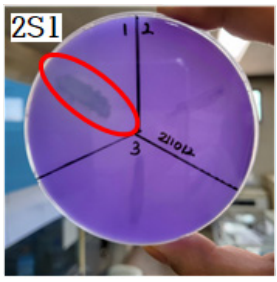

(h)

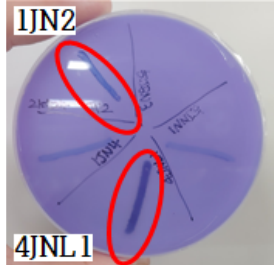

(d)

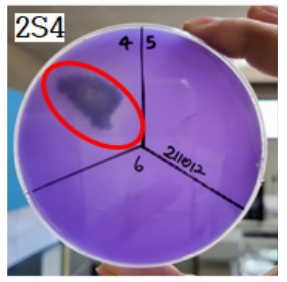

(i)

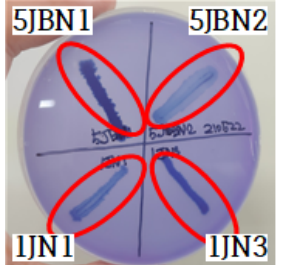

(e)

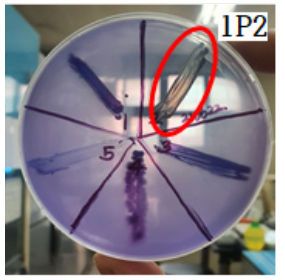

(j)

Fig. 2. Phosphoric acid solubility test using NBRIP-bpb medium. (a), Isolated strains 1B1, 1B2, 1B3, and 1B4 from Weigela subsessilis, (b), Isolated strains 2B1, 2B2, 2B3, and 2B4 from Weigela subsessilis, (c), Isolated strains 3B1, 3B2, 3B3, and 3B4 from Weigela subsessilis,(d), Isolated strains 1JN2, 1JN4, 4JNL1, 5JNN1 and 5JBN3 from Spiraea prunifolia;(e), Isolated strains 5JBN1, 1JN1, 1JN3 and 5JBN2 from Spiraea prunifolia;(f), Isolated strains 2JN5, 4JBL1, 5JNN2 and 2JN7 from Spiraea prunifolia; (g), Isolated strains 2JN2, 2JN3 and 4JBL6 from Spiraea prunifolia; (h), Isolated strains 2S1, 2S2 and 2S3 from Pennisetum alopecuroides, (i), Isolated strains 2S4, 2S5 and 2S6 from Pennisetum alopecuroides; (j), Isolated strains 1P1, 1P2, 1P3, 1P4 and 1P5 from Pine densiflora.

고, Fig.2에 NBRIP-bpb 배지를 이용한 인산가용화능 평가 결 과를 나타내었다. 인산가용화 양성반응을 보인 균주 사진의 clear zone 부위를 별도로 붉은 색의 타원으로 표기하여 확인 이 용이하도록 하였다.

이중 일부 Bacillus sp.의 경우, 생성되는 인산 분해효소 와 유기산(succinic acid, glutamic acid) 등이 인산을 가용 화시키는데 주요 기능할 것으로 보고하고 있다. ${ }^{30)}$ 본 연구 에서 분리된 Paraburkholderia terrae 1P2와 동일한 종인 Paraburkholderia phenazinium YH3, Paraburkholderia metrosideri $\mathrm{YH} 4$ 를 이용한 연구에서도 인산 가용화능을 확인 후 배지내의 유기산으로 gluconic acid와 malic acid를 검출함 으로서 유기산이 배지의 $\mathrm{pH}$ 를 감소시켜 인산가용화를 유도함 을 증명하였다. ${ }^{31)}$ 또한 상추 포트실험에서도 생육효과를 조사 하여 모든 처리구에서 $10-20 \%$ 의 생육증진효과를 확인하였다 고 보고하였다. ${ }^{31}$

\subsection{Siderophore 생성능}

철은 활성산소를 조절하고 전자전달, 신진 대사과정과 산화 환원과정에 관여하기 때문에 미생물과 식물의 대사와 생장에 필수적인 미량원소이다. ${ }^{32)}$ 토양에는 식물이 이용할 수 있는 철의 양이 매우 낮기 때문에 저분자인 siderophore를 생산하는 근권미생물이 토양에 있을 경우 이를 통해 철을 이용할 수 있게 되어 식물의 생장에 도움이 된다. ${ }^{33)}$ 또한, 이와 같은 siderophore 생성균은 중성 및 알칼리성 토양에서 활성이 있으 며, 항진균성(antifungal activity)과 연관이 있는데 이는 휘발 성 황화합물의 생성에서 기인된 것이라고 한다. ${ }^{34)}$ Siderophore
활성능은 훼손된 표토에 새로운 식생이 정착하는 과정에 식물 의 생장을 촉진하는 긍정적 역할을 할 것이다. 본 연구에서는 Chrom azurol S (CAS) blue agar를 이용하여, Siderophore 생 성능을 알아보았다. Fig.3에 Siderophore 생산능 평가 결과를 나타내었다. 병꽃나무에서 분리한 균주에서는 9개 균주, 조팝 나무에서 10 개 균주, 소나무에서는 5 개 균주, 슈크령에서 2 개 균주가 Siderophore 생성능을 보였다. Siderophore 양성반응 을 보인 균주 사진의 clear zone 부위를 별도로 붉은 색의 타원 으로 표기하여 확인이 용이하도록 하였다. 이중 병꽃나무에서 분리된 1B3, 3B4 균주와, 조팝나무에서 분리된 2JN5 균주, 소나무에서 분리된 1P1, 1P2, 1P3 균주는 매우 큰 활성을 보 였다. 그러나 최종 적용될 현장에 대한 활용성을 고려하여 인 산가용화능과 siderophore 생성능이 둘 다 있는 균주를 선별하 였다. 선별된 균주는 $1 \mathrm{~B} 1,1 \mathrm{~B} 2,1 \mathrm{~B} 3,1 \mathrm{JN} 1,1 \mathrm{JN} 2,1 \mathrm{JN} 3,2 \mathrm{JN} 5$, $4 \mathrm{JN} 1,4 \mathrm{JBL} 1,5 \mathrm{JBN} 1,5 \mathrm{JBN} 2,1 \mathrm{P} 1,1 \mathrm{P} 2,1 \mathrm{P} 3,2 \mathrm{~S} 1,2 \mathrm{~S} 4$ 으로 16 개 균주이다. 16 개 균주에 대해서 다음으로 식물생장촉진 (IAA) 및 ACC deaminase test를 수행하였다.

\subsection{IAA 생성능}

식물이 생성하는 식물호르몬인 옥신이 세포의 생장과 분화, 및 뿌리의 생장에 도움을 주는데, 미생물이 생성하고 식물이 흡수하여 식물의 생장에 도움이 되는 대표적인 호르몬인 IAA 는 옥신의 한 종류이다. ${ }^{35}$

선별된 콜로니를 대상으로 식물성 호르몬인 IAA 생산능을 측정하였다. 병꽃나무에서 분리한 $1 \mathrm{~B} 2$, 조팝나무에서 분리한 $1 \mathrm{JN} 2$, 소나무에서 분리한 $1 \mathrm{P} 2$, 수크령에서 분리한 $2 \mathrm{~S} 4$ 가 각 


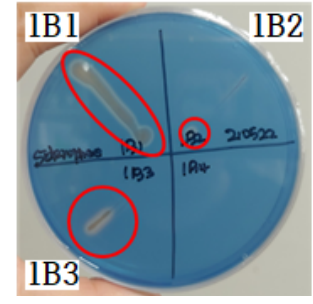

(a)

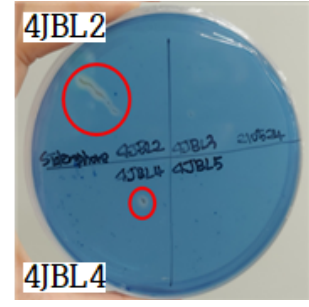

(f)

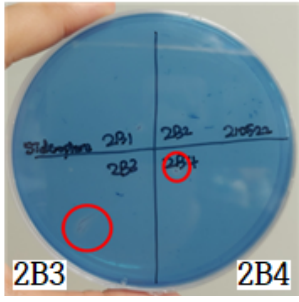

(b)

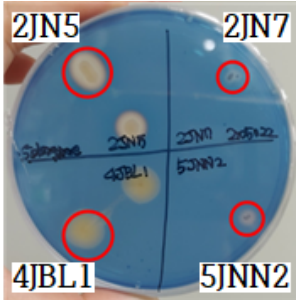

(g)

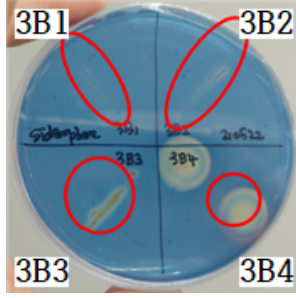

(c)

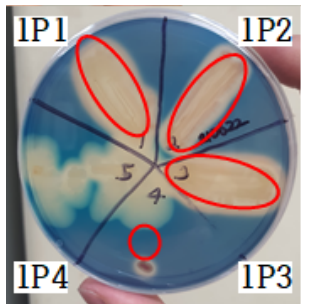

(h)

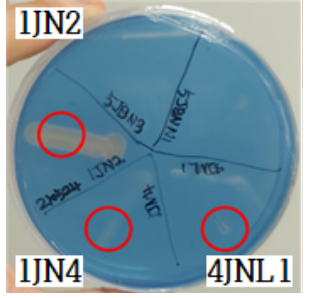

(d)

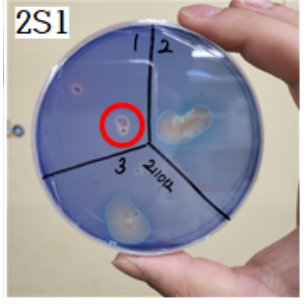

(i)

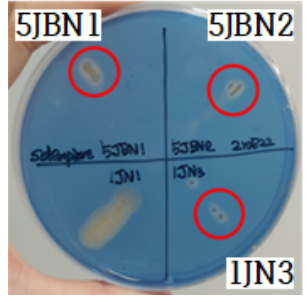

(e)

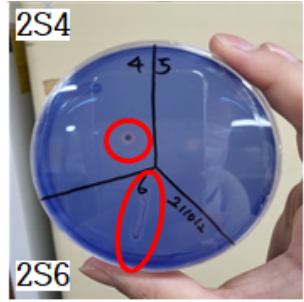

(j)

Fig. 3. Siderophore productivity test. (a), Isolated strains 1B1, 1B2, 1B3, and 1B4 from Weigela subsessilis, (b), Isolated strains 2B1, 2B2, 2B3, and 2B4 from Weigela subsessilis, (c), Isolated strains 3B1, 3B2, 3B3, and 3B4 from Weigela subsessilis,(d), Isolated strains 1JN2, 1JN4, 4JNL1, 5JBNN1 and 5JBN3 from Spiraea prunifolia; (e), Isolated strains 5JBN1, 1JN1, 1JN3 and 5JBN2 from Spiraea prunifolia;(f), Isolated strains 4JBL2, 4JBL4, 4JBL5 and 4JBL3 from Spiraea prunifolia; (g), Isolated strains 2JB5, 4JBL1, 5JNN2 and 2JN7 from Spiraea prunifolia; (h), Isolated strains 1P1, 1P2, 1P3, and 1P4 from Pine densiflora; (i), Isolated strains 2S1, 252 and 2S3 from Pennisetum alopecuroides. (j), Isolated strains 2S4, 255 and 256 from Pennisetum alopecuroides.

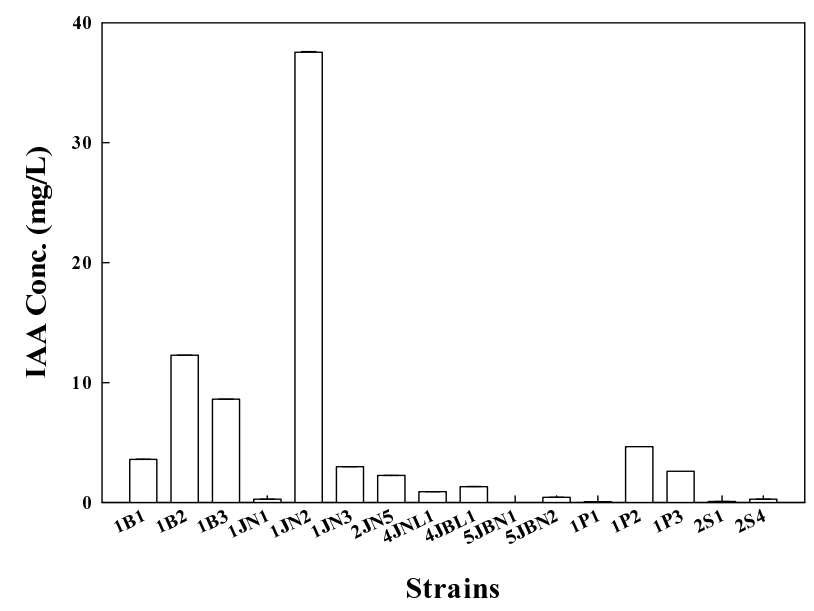

Fig. 4. IAA generative ability test.

각 $12.29 \pm 0.00,37.56 \pm 0.04,8.62 \pm 0.00,4.66 \pm 0.00,0.38 \pm 0.00$ $\mathrm{mg} / \mathrm{L}$ 로 가장 우수하였다. Fig.4에 IAA 생성능 평가 결과를 나타내었다. IAA생성을 하는 많은 PGPR이 분리되었고, 대부 분은 3-20 $\mu \mathrm{g} / \mathrm{ml}(\mathrm{mg} / \mathrm{L})$ 가량 생성하는 것으로 보고되고 있 다. ${ }^{30)}$ 그러나 IAA 생성은 식물의 생장을 초기 뿐 아니라 지속 적으로 촉진하는 것으로 알려져 단순히 화학비료를 넣어주는 것 보다 효과적으로 식물의 생육을 촉진하는 비료역할을 할 수 있다.

\subsection{ACC deaminase 활성 테스트}

건조, 염, 온도 등의 환경스트레스에 대한 저항성 기작의
주요 지표인 $\mathrm{ACC}$ deaminase 활성능을 알아보았다. $\mathrm{ACC}$ deaminase를 생산하는 근권미생물은 염분, 가뭄, 온도, 병원 성미생물 등과 같은 스트레스 요인에 따라 가속화되는 에틸 렌의 전구체인 $\mathrm{ACC}$ 를 분해하여 식물에 대한 스트레스를 저 감시켜 식물생장에 도움을 준다. ${ }^{37)}$ 미생물의 IAA 생성은 식 물의 세포생장 혹은 세포 분열을 촉진함으로서 직접적으로 혹은, ACC deaminase 활성에 의해 간접적으로 뿌리의 생장 을 향상시켜주는 것으로 알려져 있다. ${ }^{38)}$ 즉, IAA생성과 ACC deaminase 활성은 상호보완을 통해 식물생장을 향상시켜줌으 로 두 가지 활성을 동시에 나타내는 균주를 확보하는 것이 중요할 것으로 생각된다.

$\mathrm{ACC}$ deaminase 활성은 5일간 진행된 실험 중 5 일째의 $\mathrm{OD}$ 값으로 표시하였다. 병꽃나무에서 분리한 균주 중, $1 \mathrm{~B} 1$ 와 $1 \mathrm{~B} 2$ 가 활성을 가지고 있었다. 조팝나무에서 분리한 균주 중, $1 \mathrm{JN} 3$ 이 활성을 가지고 있었고, 소나무에서 분리한 균주는 $1 \mathrm{P} 1$, $1 \mathrm{P} 2,1 \mathrm{P} 3$ 이 각각 활성을 가지고 있으며, 수크령에서 분리한 균주 중 $2 \mathrm{~S} 1$ 와 $2 \mathrm{~S} 4$ 는 활성이 매우 낮은 것으로 나타났다. Fig. 5 에 ACC deaminase 활성 평가 결과를 나타내었다.

아래 Table1에 위의 식물생장촉진 능력 활성 평가 결과를 나타내었다. 이때 인산가용화능과 siderophore 활성은 정량적 평가가 어렵지만, 아래의 기준에 의거하여 활성능의 정도를 달리하였다. +++ 는 균주주변에 halo 또는 clear zone이 명확하 게(투명하게) 보여질 때이고, ++ 는 균주 주변에 halo 또는 clear zone이 생겼을 때이고, + 는 양성반응은 있지만, 사진 상 으로 halo또는 clear zone이 확인하기 어려울 때로 구분하였 
Table 1. Plant growth promotion ability activity test.

\begin{tabular}{|c|c|c|c|c|c|c|c|}
\hline \multirow{2}{*}{ Source } & \multirow{2}{*}{ Strain } & \multirow{2}{*}{ IAA (mg/L) } & \multirow{2}{*}{$\begin{array}{c}\text { ACC } \\
\text { deaminase }\end{array}$} & \multirow{2}{*}{ Siderophore } & \multicolumn{2}{|c|}{ Phosphate solubilization } & \multirow{2}{*}{ Identification } \\
\hline & & & & & PVA & NBRIP-bpb & \\
\hline \multirow{6}{*}{$\begin{array}{l}\text { Weigela } \\
\text { subsessilis }\end{array}$} & 1B1 & $3.60 \pm 0.02$ & $0.24 \pm 0.03$ & ++ & ++ & +++ & Cupriavidus sp \\
\hline & 1B2 & $12.29 \pm 0.00$ & $0.12 \pm 0.02$ & ++ & ++ & ++ & Arthrobactersp. \\
\hline & 1B3 & $8.62 \pm 0.00$ & $0.02 \pm 0.01$ & +++ & - & ++ & Pseudomonas fluorescens \\
\hline & 2B4 & $0.00 \pm 0.00$ & - & + & - & ++ & * \\
\hline & $3 B 3$ & $0.00 \pm 0.00$ & - & ++ & - & + & * \\
\hline & 3B4 & - & - & +++ & + & +++ & * \\
\hline \multirow{10}{*}{ Spiraea prunifolia } & 1JN1 & $0.28 \pm 0.00$ & $0.07 \pm 0.00$ & + & + & + & * \\
\hline & 1JN2 & $37.55 \pm 0.05$ & $0.13 \pm 0.02$ & ++ & + & +++ & Pseudomonas sp. \\
\hline & 1JN3 & $2.99 \pm 0.00$ & $0.20 \pm 0.02$ & ++ & ++ & ++ & * \\
\hline & $2 \mathrm{JN} 3$ & - & - & + & - & ++ & * \\
\hline & 2JN5 & $2.26 \pm 0.00$ & $0.15 \pm 0.02$ & +++ & + & +++ & * \\
\hline & 2JN7 & $0.19 \pm 0.00$ & - & ++ & + & - & * \\
\hline & 4JNL1 & $0.90 \pm 0.00$ & $0.20 \pm 0.02$ & + & + & + & * \\
\hline & 4JBL1 & $1.33 \pm 0.00$ & $0.17 \pm 0.01$ & + & ++ & + & * \\
\hline & 5JBN1 & - & $0.17 \pm 0.02$ & ++ & ++ & +++ & * \\
\hline & 5JBN2 & $0.44 \pm 0.00$ & $0.05 \pm 0.00$ & ++ & - & + & * \\
\hline \multirow{3}{*}{ Pine densiflora } & 1P1 & $0.07 \pm 0.00$ & $0.16 \pm 0.01$ & +++ & + & - & * \\
\hline & $1 \mathrm{P} 2$ & $4.66 \pm 0.00$ & $0.16 \pm 0.01$ & +++ & ++ & +++ & Paraburkholderia terrae \\
\hline & $1 \mathrm{P} 3$ & $2.60 \pm 0.00$ & $0.19 \pm 0.00$ & +++ & ++ & - & * \\
\hline \multirow{2}{*}{$\begin{array}{l}\text { Pennisetum } \\
\text { alopecuroides }\end{array}$} & 251 & - & $0.06 \pm 0.00$ & ++ & + & ++ & * \\
\hline & 254 & $0.38 \pm 0.00$ & $0.02 \pm 0.00$ & ++ & - & +++ & Streptomyces sp. \\
\hline
\end{tabular}

$*$ : not identified

-, negative $;+$, positive; ++ , weak positive; +++ , stronger activity

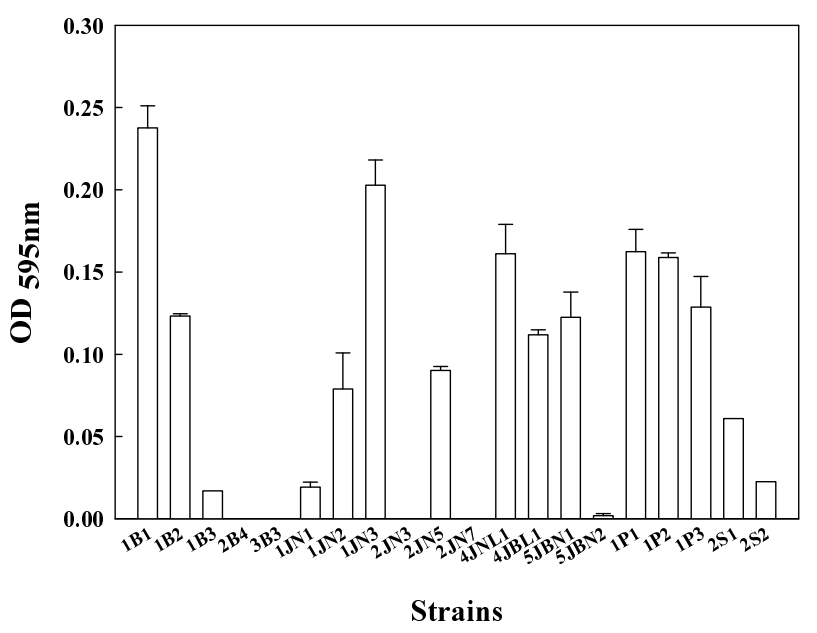

Fig. 5. ACC deaminase activity test.

다. 이와 같은 구분은 Huo 등의 논문에서 분류한 기준을 근거 로 참고하였다. ${ }^{39)}$

\subsection{Pot 실험을 이용한 분리균주의 식물생장촉진능 생물검정}

식물생장촉진미생물을 식물에 접종하는 방법은 식물종자 코팅법, 모종 뿌리 토양에 배양액 주입법, 식물생장촉진미생 물을 고정한 담체를 토양에 주입하는 법 등이 있는데, 본 연구
에서는 모종 뿌리에 배양액을 주입하였다. 많은 식물생장촉진 미생물의 생물검정은 기장, 옥수수, 버들, 유채, 벼와 같은 초 본류에 대한 적용이 대부분이며 본 연구에서와 같은 관목류에 적용한 예는 매우 드물다. 생물검정을 위한 관찰기간이 길어 지고 식물생장을 측정하기 어렵기 때문이다. 대부분 초본류에 는 줄기 길이, 뿌리 길이, 줄기 건조중량, 뿌리 건조 중량 등을 측정하는데 관목류를 주기적으로 관찰할 경우 줄기 길이의 변화가 크지 않고 개체 크기가 커서 뿌리 길이나, 줄기와 뿌리 의 건중량을 측정하기 어렵다. 그러나 훼손된 표토를 관목 식 재를 통한 복원과정에 이와 같은 식물생장촉진미생물의 적용 가능성을 알아보기 위한 실험을 진행하였다.

Alguacil 등이 발표한 바에 의하면 ${ }^{40)}$ 반건조화된 황폐한 토 양지대에 올리브 나무에 AM fungi 접종 후 14개월 후 모든 식물에서 유의적 증가를 관찰하였다고 한다. 다만, 이러한 효 과는 접종균과 토착균의 상호작용에 의하여 매개된 결과로 생각하였다. 본 연구와 달리 오랜 기간의 연구로 유의적 결과 를 볼 수 있었다.

국내 파로호 주변의 훼손된 불모지에 Pseudomonas fluorescens 균주 3종류와 강원도 산림토양에서 분리된 Bacillus megaterium 와 Azotobacter vinelandii 균주를 파로호 주변 우점종 종자에 적용하여 재식생을 시도한 결과, 73 일의 현장실험에서 실험군 이 대조군 보다 줄기 및 뿌리 생장을 $50 \%$ 가량 향상시켜 주었다 

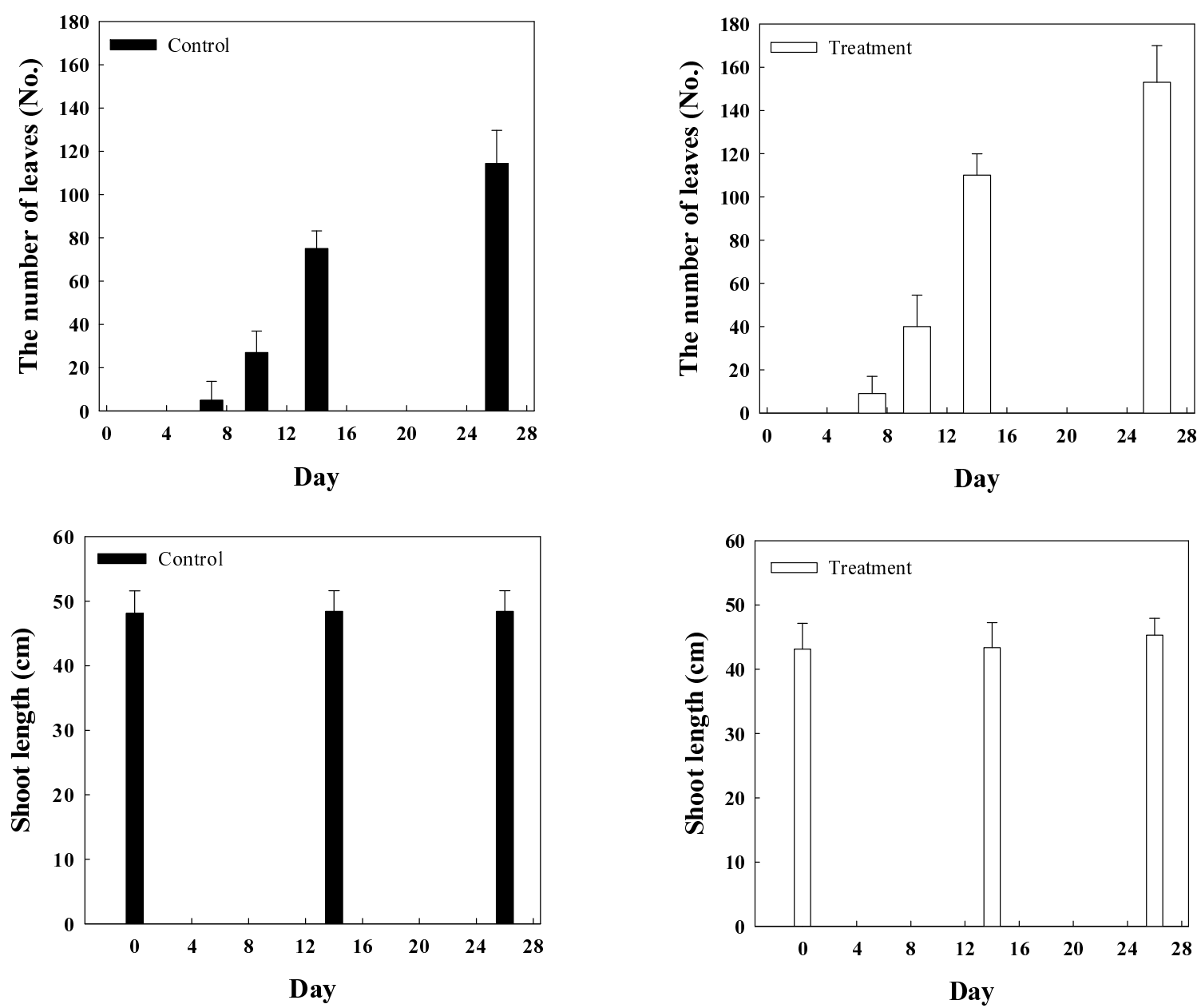

Fig. 6. Comparisons of leaves and stem length of control group ( $\square$ ) and experimental group ( $\square$ ) of Weigela subsessilis.

고 한다. ${ }^{41)}$ 다만, 이 경우 초본류를 대상으로 하는 점은 본 연구와의 차이라고 볼 수 있다.

본 연구는 2 달여의 관찰 기간 동안 관목류의 생장변화를 줄 기길이를 통해 확인하기 어려워 잎의 엽록소 생성량 및 잎수 변화를 관찰하였다.

병꽃나무에서 분리되어 동정된 Arthrobacter sp. $1 \mathrm{~B} 2$ 를 병 꽃나무에 접종한 실험군과 균주가 접종되지 않은 대조군의 생장을 확인하였다(Fig. 6). 실험 개시 전 모두 잎을 제거한 후 실험을 시작하고 잎수의 변화를 살펴본 결과 미생물을 접 종한 실험군은 미접종한 대조군에 비하여 잎수에 큰 차이를 보여 평균 잎수가 대조군에 비하여 $33 \%$ 높았다. 줄기 길이의 변화는 관목류의 특성상 크지 않아 실험 1 개월의 실험 기간 동안 큰 변화는 없었다. 병꽃나무는 봄철에 개화 후 생장이 활발한 특성이 있는데, 가을철 기온이 저하됨에 따라 단풍과 낙엽이 진 후 더 이상의 실험 관측이 진행되지 못했다.

Rahman 등(2018)은 Bacillus amylolequefacoems BChi1과 Parburkholderia fungorum BRRh-4를 이용한 딸기 생육에 미 치는 영향을 살펴보기 위하여 뿌리에 미생물을 접종한 후 스 프레이처리를 한 결과, 과일의 생산이 비 처리구에 비하여
$48 \%$ 향상되었음을 보고하였다. 또한, 뿌리생육과 줄기 생장 에도 영향을 미치고, 캐로티노이드, 플라보노이드 및 안토시 아닌과 같은 항산화물질의 함량이 증가함을 보고하였다. ${ }^{42}$ 소나무에서 분리된 Paraburkholderia terrae를 배양하여 준 비한 후 동일하게 접종한 실험군과 대조군의 생장에 미치는 영향을 알아보았다(Fig.7). 소나무 역시 줄기생장이 매우 느 린 관목류여서 1 개월간의 실험기간 동안 큰 변화는 없었다. 다만 엽록소 함량을 측정한 결과 실험군은 초기 실험 개시 14 일에 측정하고 이후 40 일에 측정하여 1 개월이 경과하는 동안 $89.7 \%$ 증가한 반면 대조군은 $74.7 \%$ 증가하였다. 실험 69 일 째 결과에서는 소나무 줄기는 초기값에 비해 대조군은 $5.8 \%$ 증가하였으며 실험군은 $8.1 \%$ 증가하였다. 소나무 엽록 소는 14 일값에 최초 측정일 대비해서 대조군은 $283.3 \%$ 증가, 실험군은 $390.6 \%$ 증가하였다.

본 연구진은 과거 Arthrobacter scleromae SYE-3을 나이지 리아 작물재배 지역의 근권토양에서 분리한 후 Yam 생장에 미 치는 영향을 살펴본 결과 112 일의 실험경과 후 대조군에 비하 여 실험군에서 줄기길이와 뿌리생장이 각각 $190 \%$ 와 $282.4 \%$ 향상됨을 관찰하여 생물비료로서의 잠재적 능력을 확인하였 


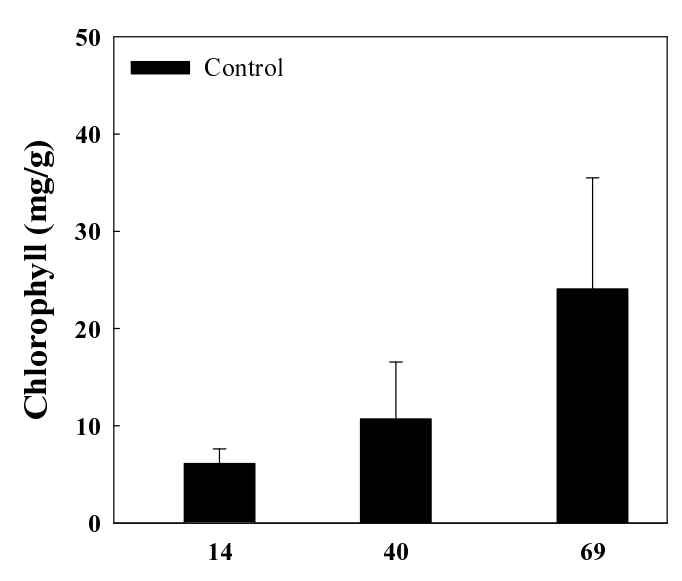

Day

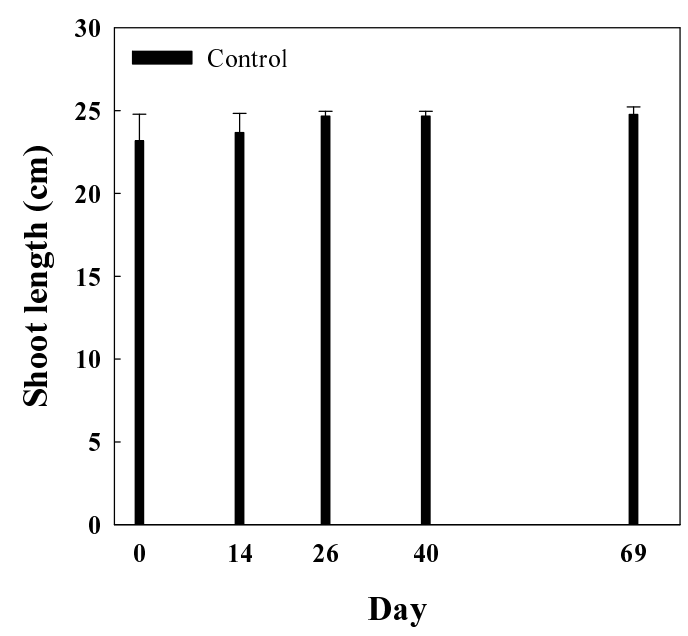

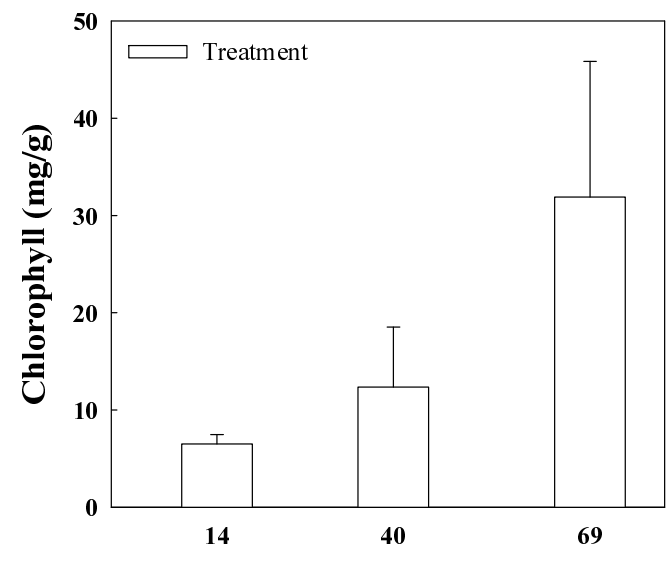

Day

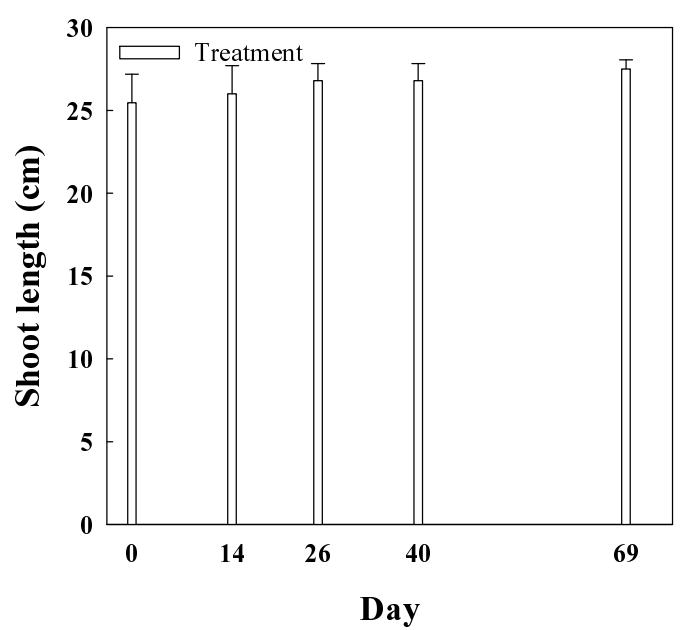

Fig. 7. Comparisons of chlorophyll and stem length of control group ( $\square$ ) and experimental group ( $\square$ ) of Pinus densiflora.

다. ${ }^{26)}$ 또한, 인이 결핍되고 염이 축적된 토양에 Arthrobacter sp. 와 Bacillus sp.를 접종하여 줄기 및 뿌리 생장에 큰 향상을 보여주는 예도 있다. ${ }^{43)}$ 다양한 환경요인 중 인 결핍 단독 환경 이나 염 축적 단독 환경에 비하여 두 가지 스트레스가 있는 경우 횔씬 더 심각한 식물생장의 손상을 받게 되는데, 이 경우 근권 균주는 $\mathrm{Na}^{+}$이온의 흡수를 제한하고 $\mathrm{K}^{+}$이온의 흡수를 증 가시켜주면서 식물의 생장을 향상시켜주는 것을 밝혔다. 또 한, 인의 흡수가 $32.5 \%$ 에서 $154.5 \%$ 까지 증가시켜주었고 결국 식물생장을 촉진하는 것으로 나타났다. 일부 종에서는 인 흡 수 활성이 없이도 식물생장이 촉진되는 경우도 있다.

\section{4. 결 론}

기존의 초본류에서 분리된 식물생장촉진미생물과 달리 관 목류로부터 다양한 식물생장촉진미생물(PGPR)을 분리하고 이들의 식물생장촉진활성을 확인하였다. 기존 초본류의 단기 간에 걸친 식물생장촉진과는 달리 관목류의 생장이 느리기 때문에 측정된 활성은 길이생장을 관여하는 IAA값이 기존 연 구진이 분리하였던 PGPR 보다 높지 않았으며, 척박한 토양에
잘 견디기위해 필요한 인 및 철의 활용능력과 관련된 인 가용 화활성 및 siderophore 활성이 우수한 균주가 많았다. 관목류 는 생장의 변화를 단기간에 관찰하기 매우 어려워서 실험초기 줄기길이를 모두 동일하게 절단해줌은 물론 모든 잎을 제거하 여 잎의 출현을 관찰하였다. 또한 소나무와 같은 침엽수는 잎 을 제거하기 어렵기 때문에 엽록소 함량을 측정함으로서 주기 적 측정값으로 활용하였다. 본 연구를 이용하여 표토훼손지의 식생재녹화를 통한 복원을 위하여 식물생장촉진미생물을 이 용하여 현장적용 가능성을 확인할 수 있었다.

\section{Acknowledgement}

본 연구는 한국환경산업기술원의 연구비 지원으로 수행되 었습니다(과제번호: 202000284001). 이에 감사드립니다.

\section{References}

1. C. H. Kang, A study on the introduction of conservation of top soil into the environmental assessment system, 
KwangWoon University, PhD Thesis(2013).

2. Ministry of Environment, Evolutionary methodology study for soil and groundwater economic value evaluation(2010).

3. B. O. Cho, Characterization of soil fertility and management practices of alpine soils under vegetable cultivations, KwangWoon University, PhD Thesis(1999).

4. J. H. So, F. J. Kim, J. H. Shin, C. B. Yu, I. K. Rhee, Isolation and characterization of Bacillus ce reus A-130 producing auxin from east coast sand dunes, Kor. J. Environ. Agr., 28(4), 447-452 (2009).

5. J. S. Jeong, H. K. Kim, S. J. Lee, S-W. Jeong, Effects of diesel dose and soil texture on variation in the concentration of total petroleum hydrocarbon in the diesel-contaminated soil, J. Korean Soc. Environ. Eng., 37(1), 69-72(2015).

6. R. D. Souza, A. Ambrosini, L. M. Passagila, Plant growth-promoting bacteria as inoculants in agricultural soils, Genet. Mol. Biol., 38(4), 401-419(2015).

7. X. H. Fan, S. A. Zhang, X. D. Mo, Y. C. Li, Y. Q. Fu, Z. G. Liu, Effect of Plant growth-promoting rhizobacteria and $\mathrm{N}$ source on plant growth and $\mathrm{N}, \mathrm{P}$ uptake by tomato growth in calcareous soils, Pedosphere, 27(6), 1027-1036 (2017).

8. Y. Xiao, X. Wang, W. Chen, Q. Huang, Isolation and identification of three potassium-solubilizing bacteria from rape rhizospheric soil and their effects on ryegrass, Geomicrobiol. J., 34(10), 873-880(2017).

9. M.Z. Mumtaz, M. Ahmad, M. Jamil, T. Hussain, Zn solubilizing Bacillus spp. potential candidates for biofortification in maize, Microbiol. Res., 202, 51-60(2017).

10. S. M. Kang, M. Wagas, R. Shahzad, Y. H. You, S. Asaf, M. A. Khan, K. E. Lee, G. J. Joo, S. J. Kim, I. J. Lee, Isolation and characterization of novel silicate-solubilizing bacterial strain Burkholderia eburnea CS4-2 that promotes growth of japonica rice(Oryza sativa L. cv. Dongjin). Soil Sci. Plant Nutr., 63(3), 233-241(2017).

11. S. Y. Lin, A. Hameed, Y. C. Liu, Y. H. Hsu, W. A. Lai, F. T. Shen, Azospirillum soli sp. nov., a nitrogen fixing species isolated from agricultural soil, Int. J. Syst. Evol. Microbiol., 65, 4601-4607(2015).

12. C. Y. Jiang, X. F. Sheng, M. Qian, Q. Y. Wang, Isolation and characterization of a heavy metal-resistant Burkholderia sp. from heavy metal-contaminated paddy field soil and its potential in promoting plant growth and heavy metal accumulation in metal-polluted soil, Chemosphere, 72(2), 157-164(2008).

13. S. B. Sharma, R. Z. Sayyed, M. H. Trivedi, T. A. Gobi, Phosphate solubilizing microbes; sustainable approach for managing phosphorus deficiency in agricultural soils, SpringerPlus, 2, 587-600(2013).

14. I. Mohamed, K. E. Eid, M. H. H Abbas, A. A. Salem, Use of plant growth promoting rhizobacteria (PGPR) and mycorrhizae to improve the growth and nutrient utilization of common bean in a soil infected with white rot fungi, Ecotoxicol. Environ. Saf., 171, 539-548(2019).

15. J. H. Kim, J. C. Joo, G. W. Bang, E. B. Kang, J. S. Choi,
Y. H. Kim, A study on leaching characteristics of coal bottom ash for construction site runoff control, in Proceedings of the Annual Meeting of Korean Society of Environmental Engineers, KSEE, Gwangju, pp. 355-356(2018).

16. W. Radzki, F. G. Mañero, E. Algar, J. L. García, A. García-Villaraco, B. R. Solano, Bacterial siderophores efficiently provide iron to iron-starved tomato plants in hydroponics culture, Antonie Van Leeuwenhoek, 104(3), 321-330(2013).

17. S. H. Hong, E. Y. Lee, Vegetation restoration and prevention of coastal sand dunes erosion using ion exchange resins and the plant growth-promoting rhizobacteria Bacillus sp. SH1RP8 isolated from indigenous plants, Int. Biodeter. Biodegr., 95, 262-269(2014).

18. A. A. Belimov, V. I. Safronova, T. A. Sergeyeva, T. N. Egorova, V. A. Matveyeva, V. E. Tsyganov, A. Y. Borisov, I. A. Tikhonovich, C. Kluge, A. Preisfeld, K. J. Dietz, V. V. Stepanok, Characterization of plant growth promoting rhizobacteria isolated from polluted soils and containing 1-aminocyclopropane-1-carboxylate deaminase, Can. J. Microbiol., 47(7), 642-652(2001).

19. C. Forni, D. Duca, B. R. Glick, Mechanisms of plant response to salt and drought stress and their alteration by rhizobacteria, Plant Soil, 410, 335-356(2017).

20. H. Etesami, D. K. Maheshwari, Use of plant growth promoting rhizobacteria (PGPRs) with multiple plant growth promoting traits in stress agriculture: action mechanisms and future prospects, Ecotox. Environ. Saf., 156(30), 225-246(2018).

21. B. R. Glick, Bacteria with ACC deaminase can promote plant growth and help to feed the world, Microbiol. Res., 169(1), 30-39(2014).

22. J. L. Schnoor, Phytoremediation: Technology evaluation report(TE-98-01), Ground water remediation technologies analysis center, Iowa City, Iowa, USA.

23. F. Ahmad, I. Ahmad, M. S. Khan, Screening of free-living rhizospheric bacteria for their multiple plant growth promoting activities, Microbiol. Res., 163(2), 173-181(2008).

24. B. R. Glick, D. M. Penrose, J. Li, A model for the lowering of plant ethylene concentrations by plant growth-promoting bacteria, J. Theor. Biol., 190(1), 63-68(1998).

25. A. M. Milagres, A. Machuca, D. Napoleao, Detection of siderophore production from several fungi and bacteria by a modification of chrome azurol S (CAS) agar plate assay, J. Microbiol. Methods., 37(1), 1-6(1999).

26. S. H. Hong, J. S. Kim, J. G. Shim, E. Y. Lee, Isolation and characterization of the plant growth promoting rhizobacterium, Arthrobacter scleromae SYE-3 on the Yam growth, KSBB J., 31, 58-65(2016).

27. E. Dell's Amico, L. Cavalca, V. Andreoni, Analysis of rhizobacterial communities in perennial Graminaceae from poluted water meadow soil, and screening of metalresistant, potentially plant grwoth-promoting bacteria, FEMS microbial. Ecol., 52(2), 153-162(2005).

28. B. Hameeda, G. Harini, O. P. Repula, S. P. Wani, G. Reddy, Growth promotion of maize by phosphate-solubilizing 
bacteria isolated from composts and macrofauna, Microbiol. Res., 163, 234-242(2008).

29. S. Mundra, R. Arora, T. Stobdan, Solubilization of insoluble inorganic phosphates by a novel temperature-, $\mathrm{pH}-$, and salt-tolerant yeast, Rhodotorula sp. PS4, isolated from seabuckthorn rhizosphere, growing in cold desert of Ladakh, India, World J. Microbiol. Biotechnol., 27, 2387-2396(2011).

30. N. Raddadi, A. Cherif, A. Boudabous, D, Daffonchio, Screening of plant growth promoting traits of Bacillus thuringiensis, Ann. Microbiol, 58(1), 47-52(2008).

31. H.-J. Yu, M.-H. Yoon, Phosphate solubilizing effect by two paraburkholderia bacteria isolated from button mushroom medium, J. Mush., 17(2), 64-69(2019).

32. S. X. Li, Z. H. Wang, B. A. Stewart, Response of crop plants to ammonium and nitrate N, Adv. Agron., 118, 205-397(2013).

33. R. C. Hider, X. Kong, Chemistry and biology of siderophores, Nat. Prod. Rep., 27(5), 637-657(2010).

34. V. J. Carrión, V. Cordovez, O. Tyc, D. W. Etalo, I. de Bruijn, V. C. L. de Jager, M. H. Medema, L. Eberl, J. M. Raaijmakers, Involvement of Burkholderiaceae and sulfurous volatiles in disease-suppressive soils, ISME J., 12, 2307-2321(2018).

35. S. Spaepen, J. Vanderleyden, Auxin and plant-microbe interactions, Cold Spring Harb. Perspect. Biol., 3(4), a001438 (2011).

36. S. Banerjee, R. Palit, C. Sengupta, D. Standing, Stress induced phosphate solubilization by Arthrobacter sp. and Bacillus sp. isolated from tomato rhizosphere, Aus. J. Crop Sci., 4, 378-382(2010).

37. S. H. Hong, M. H. Lee, J. S. Kim, E. Y. Lee, An evaluation of plant growth promoting activities and salt tolerance of rhizobacteria isolated from plants native to coastal sand dunes, Microbiol. Biotechnol. Lett., 40(3), 261-267(2012).

38. Y. S. Kim, M. H. Yoon, Plant growth promotion effect of Klebsiella michiganesis Jopap-1 isolated from button mushroom bed, J. Mush., 16(3), 218-224(2018).

39. Y. Huo, J. P. Kang, J. C. Ahn, Y. J. Kim, C. H. Piao, D. U. Yang, D. C. Yang, Siderophore-producing rhizobacteria reduce heavy-metal-induced oxidative stress in Panax ginseng Meyer, J. Ginseng Res., 45(2), 218-227(2021).

40. M. del M. Alguacil, E. Torreciullas, J. Kohler, A. Roldán, A molecular approach to ascertain the success of "in situ" AM fungi inoculation in the revegetation of a semi grid, degraded land, Sci. Total Environ., 409(15), 2874-2880 (2011).

41. T. S. Ahn, J. O. Ka, G. H. Lee, H. G. Song, Revegetation of a Lakeside Barren Area by the Application of Plant
Growth-promoting Rhizobacteria, The Journal of Microbiology, 45(2), 171-174(2007).

42. M. Rahman, A. A. Sabir, J. A. Mukta, M. M. A. Khan, M. Mohi-Ud-Din, G. Miah, M. Rahman, Plant probiotic bacteria Bacillus and Paraburkholderia improve growth, yield and content of antioxidants in strawberry fruit, Scientific reports, 8(1), 2504(2018).

43. T. T. G. Vanissa, B. Berger, S. Patz, M. Becker, V. Turečkova, O. Novák, D. Tarkowská, F. Henri, S. Ruppel, The response of Maize to inoculation with Arthrobacter sp. and Bacillus sp. in phosphorus-deficient, salinity-affected soil, Microorganisms, 8(7), 1005-1022(2020).

\section{Declaration of Competing Interest}

The authors declare that they have no known competing financial interests or personal relationships that could have appeared to influence the work reported in this paper.

\section{Authors and Contribution Statement}

\section{Ji Seul Kim}

Department of Environmental Energy Engineering, The University of Suwon, Ph.D. Candidate, ORCiD (1) 0000-0002-6595-621X: Conceptualization, Data curation, Data analysis, Methodology, Visualization, Writing - original draft, Writing - review and editing, Funding acquisition, Project administration, Resources, Supervision, Validation, Visualization.

\section{Jun Ho Kim}

Department of Environmental Energy Engineering, The University of Suwon, Master Candidate, ORCID (1) 0000-0003-2060-0073: Conceptualization, Data curation, Data analysis, Methodology, Visualization, Writing - original draft, Writing - review and editing, Funding acquisition, Project administration, Resources, Supervision, Validation, Visualization.

\section{Eun Young Lee}

Department of Environmental Energy Engineering, The University of Suwon, Head Manager, ORCiD (C) 0000-0003-2008-083X: Funding acquisition, Project administration, Resources, Writing review and editing. 